IRA-International Journal of Education \&

Multidisciplinary Studies

QUARTERLY

ISSN 2455-2526; Vol.16, Issue 04 (Oct.-Dec., 2020)

Pg. no. 243-247.

Institute of Research Advances

https://research-advances.org/index.php/IJEMS

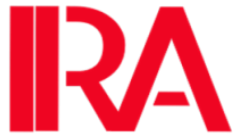

\title{
Thematic Contrast between The Story of Xu Sanguan Selling Blood and The Old Man and The Sea
}

Chen Mengxia

School of Foreign Languages, Yangtze University, Jingzhou, Hubei, China.

Type of Work: Peer-Reviewed

DOl: http://dx.doi.org/10.21013/jems.v16.n4.p5

\section{How to cite this paper:}

Mengxia, C. (2020). Thematic Contrast between The Story of Xu Sanguan Selling Blood and The Old Man and The Sea. IRA International Journal of Education and Multidisciplinary Studies (ISSN 2455-2526), 16(4), 243-247. DOl: http://dx.doi.org/10.21013/jems.v16.n4.p5

(C) Institute of Research Advances.

This work is licensed under a Creative Commons Attribution-NonCommercial 4.0 International License subject to a proper citation to the publication source of the work.

Disclaimer: The scholarly papers as reviewed and published by the Institute of Research Advances (IRA) are the views and opinions of their respective authors and are not the views or opinions of the IRA. The IRA disclaims of any harm or loss caused due to the published content to any party.

Institute of Research Advances is an institutional publisher member of Publishers International Linking Association Inc. (PILA-CrossRef), USA. The institute is an institutional signatory to the Budapest Open Access Initiative. Hungary advocating the open-access of scientific and scholarly knowledge. The Institute is a registered content provider under Open Access Initiative Protocol for Metadata Harvesting (OAI-PMH).

The journal is indexed \& included in WorldCat Discovery Service (USA), CrossRef Metadata Search (USA), WorldCat (USA), OCLC (USA), Open J-Gate (India), EZB (Germany) Scilit (Switzerland), Airiti (China), Bielefeld Academic Search Engine (BASE) of Bielefeld University, Germany, PKP Index of Simon Fraser University, Canada. 


\begin{abstract}
Thematic study plays an important role in comparative literature. With the perspective of the thematic approach in comparative literature, readers can better understand the content of different texts and recognize the characteristics of each text. Moreover, readers can also have a glimpse of some creative ideas and personalities of different writers by exploring their treatment of the same or similar theme. This paper aims to compare the two novels, The Story of $X u$ Sanguan Selling Blood and The Old Man and The Sea, to elaborate on the themes of suffering and redemption, tragedy, kindness, and to explore the similarities and differences between them.
\end{abstract}

Keywords: theme, suffering and redemption, tragedy, kindness, and love

\title{
1. Introduction
}

Yu Hua, the author of The Story of Xu Sanguan Selling Blood, and Hemingway, the author of The Old Man and The Sea, are both successful novelists in the history of China and the United States. Therefore, they have endless researches at home and abroad. In addition, with the publication and award-winning of Yu Hua's novels abroad, there has been an upsurge in the study of Yu Hua's novels. "Generally speaking, the research about his works in the past ten years has been carried out from five aspects: the writer's thought, the theme, the form research, the image analysis, and the comparative study... [1]. Hemingway, as the leader of the "lost generation" in the United States, it has been a lot of studies on his works, especially "in the study of The Old Man and The Sea, most of the studies have been on its theme, 'Christian theme interpretation', 'implication of the author and writing', 'dialogue between man and nature', 'theme of love', etc.” [2].

The Story of Xu Sanguan Selling Blood tells a story about the man, Xu Sanguan, selling blood 12 times, because of his curiosity, before and after he married with the so-called "blood money". It describes the oppression of the complex social environment on the people living in that era and reflects people's helplessness for the "blood selling tide" at that time. Yu Hua once commented on himself that "for a long time, my works have been derived from the tension with reality" [3]. Therefore, it is not difficult to find that most of his works were created in the period of China's "Great Leap Forward" and "Cultural Revolution". The Old Man and The Sea was adapted by Hemingway after World War II, according to the true story of a real man. Santiago, the protagonist of the novel, still insists on fishing, on the condition that after 84 days he didn't catch anything and almost starving to death. Ultimately, on the 85th day, he met a large Marlin and he finally returned home, after several days of fighting. During this period, he encountered a lot of attacks, so he only took the fish bones of the marlin back. The full text rendered an atmosphere of sadness but does not say defeat. There are great similarities in the ideological content of the two novels, which greatly reflects the resemblances between human cultures born in different periods. At the same time, through the shaping of these two characters, it also reflects the different cultures have different interpretations and expressions of the same image.

\section{Themes}

\subsection{The theme of suffering and redemption}

Both $\mathrm{Xu}$ Sanguan and Santiago are typical images of suffering. "Suffering refers directly to the 
ultimate life tragedy, and to the survival dilemma that people must face directly"[4]. Except for Xu Sanguan's first curiosity, he went to sell blood because his son had to pay for his injury, or when the whole family was not full. Therefore, generally speaking, he did not sell blood voluntarily, but he had to. It's the second case of suffering, in which the survival dilemma that people had to face directly comes from the pressure in all aspects of life, such as the difficulty from works and hardship from their own family. Similarly, Santiago's persistent fishing for himself not to be starved to death, not to be looked down upon by others, and he has a strong will not admit defeat and rush forward. The reason people are able to face these hardships and difficulties in life, its because they went to get rid of the suffering in life. Just like the starvation that Xu Sanguan and Santiago want to cast off, if they can't get through these toughs, there will be another suffering waiting for them. Because "'suffering' is the essence of human life, and 'living' is the purpose of human existence"[5]!

There will be redemption if there is suffering. For Xu Sanguan, his redemption is to change his mentality and attitude. He had to climb out of his misery and to resist. Even if the ending is doomed to be sad, what we have to do is to exhaust our best and do everything well. "There is no destiny that punishes people. As long as we try our best to do everything, it should be a happy ending. To live in the face of suffering and tragic fate, people say "yes" to life is a kind of resistance, which is to endow human life with value and significance"[4]. Facts have proved that Xu Sanguan finally saved himself. He knew that he could not donate blood because he was old, but he accepted the reality and get out of the curse of "can not selling blood". In The Old Man and The Sea, Santiago's redemption is "returning to nature... admitting that a man is very small in nature is the real redemption of mankind" [6]. To admit one's insignificance is to recognize that fate is unchangeable. The power of nature is enormous, but negligible is human beings. If Santiago does not attribute his failure to his incompetence but realizes that his power is not worth mentioning in the contrast of nature, he is his salvation.

Suffering is not terrible, as long as people have the courage to face these plights of life, finally, they will be redeemed.

\subsection{The theme of tragedy}

Tragedies can be generally divided into the bad things that others bring to themselves, or some undesirable outcomes caused by their own reasons. As Schopenhauer once classified tragedies into three categories: "one is the tragedy caused by people's 'extraordinary and full play of malice', that is, the tragedy created by the wicked; the second is the tragedy caused by 'blind fate, which is accidental and wrong', and that is, the tragedy of fate; the third is the tragedy caused by people's 'different status and relationship', it is the tragic power beyond the scope of human ability"[7].

Neither Xu Sanguan nor Santiago has been persecuted by the wicked. But the causes of Xu Sanguan's tragedy are some inevitable reasons, that is, the manipulation of fate. "All my efforts in works are to get close to the facts", Yu Hua said. No one can predict what era they will be living in, and no one can imagine what changes will be happened to the society where they are living in. Having never experienced the days of smashing pots, selling iron, and eating canteens in the "Great Leap Forward" period, Xu Sanguan will never realize that his family needs to rely on their own wonderful cooking speech to meet their food needs; if Xu Sanguan does not experience Xu Yulan's "Da zi bao", he would never have the thought that both he and his children should have a critical meeting to their wives and 
mothers. That is the control of fate, which no one can escape. This is also one reason for a tragedy, no matter who is unable to predict who he will meet or what he will experience. For human beings, all life is "feeling the stone and across the river", step by step.

Santiago's tragedy should belong to the third kind, and the tragedy he suffered should be a force beyond his own ability. After 84 days of fruitless fishing, Santiago must go further and more dangerous deep sea, where no one else wanted to go. He has a long way to go with himself alone, in addition, he has passed the age when he can accept his own conceit, and then a tragedy occurs. Supposing that, in the offshore, he caught the Marlin fish with partners around, and he is so young and strong, certainly he will not be in vain. It's because he overestimated his own power or underestimated the power of nature that he did something beyond his ability, which led to the tragedy of the 85th day which was still unproductive.

\subsection{The theme of kindness and love}

In Chinese and foreign literary works, texts with full darkness, gloom, and depression are rare. Most of the works will convey some so-called positive energy. These two texts are no exception.

At the beginning of learning that Xu Yile was not his own child, Xu Sanguan hated He Xiaoyong. However, when He Xiaoyong had a car accident and needed Yile to call his soul, Xu Sanguan not only agreed but also encouraged Yile to shout, so that He Xiaoyong's soul would be heard and come back to life, which showed the simplicity and kindness of the people at that time; and "Li Xuetou" who drew blood, was originally a down-to-earth ordinary citizen who was selfish. However, when Xu Sanguan begged him to take more blood so that Xu can buy something to curry favour with Erle's leader, then his son, Erle, would back to the city as soon as possible. Although Li Xuetou would take responsibility if some bad things happened, he was still distressed by the parents' longing for their children and agreed to Xu Sanguan. Therefore, the quality of a person can not only look at the surface, nor just one thing, it should be compared. No one can say that Li Xuetou is a completely cold-blooded person. The warmest, kind, and loving time in the novel, should be Xu Sanguan's last selling blood time to save Xu Yile. When people saw Xu Sanguan, an old man in his fifties, drinking the cold water from the river bowl by a bowl on a cold day, most people ran over to ask him the reason, and they said that if $\mathrm{Xu}$ needs any help, they would reach out of their help one by one. This matter, no matter Xu Sanguan, Xu Yile, or readers, will be touched.

In The Old Man and The Sea, the greatest kindness that can be felt is the relationship between Manolin and Santiago. During the time when Santiago struggled with the big marlin and was drifting on the sea, he was afraid that Manolin was too worried about himself. In turn, he believed in Manolin's feelings for himself. It was a feeling of mutual trust and love, just like between parents and children. And then, after Santiago came back, Manolin's feeling was that "when he saw the old man's hands bruised by the fishing rope, he cried. He quietly went out to fetch coffee for the old man, and he cried all the way." Because he loved the old man's crying, and he later said that no matter whether his parents agreed or not, he would take care of him in front of San Diego and go to sea with him. This is a loving and kind-hearted child. 


\section{Conclusion}

Yu Hua's works put the individual in a complex historical, political, and social environment, describing the confrontation between the small or low-level characters and the powerful social environment, and revealing the irresistible fate. Hemingway expressed his theme of "a man can be destroyed but not defeated" through his description of Santiago, and described the smallness of man in front of nature. This paper discusses the themes of suffering and redemption, tragedy and kindness and love in the two articles, and finds out their similarities and differences. Xu Sanguan spent his whole life to consider the suffering and the irresistible fate of Santiago in a few days.

\section{References}

[1]. Chang Qie\& Ye Li. (2001). Suffering and Redemption: Two main themes of Yu Hua's novels in the 1990s. Journal of Huazhong University of Science and Technology (Social Science Edition), 15 (2), 96-101.

[2]. Ma Xinguo. (2002). History of Western Literary Theory[M]. Higher Education Press.

[3]. Peng Aihua. (2006). Review of Yu Hua's Research in Recent Ten Years.

[4]. Song Jianhua \& Zhan Lin (2012). The Story of Xu Sanguan Selling Blood: An Absurd and True Narration of Suffering [J]. Qilu Journal, (02): 135-140.

[5]. Su Ye. (2009). On the Three Aspects of the Tragic Theme of The Old Man and The Sea. World Literature Review, 195-199.

[6]. Wu Jing (2005). Taking Love as the Theme -- Reading Hemingway's The Old Man and The Sea. Social Sciences, 020 (004), 234-235.

[7]. Xue Shichang. (2010). Human Demeanor, Human Destiny and Human Salvation -- a new discussion on the theme of Hemingway's The Old Man and The Sea. Journal of Tianshui Normal University (03), 30-33.

[8]. Yu Hua \& Yang Shaobin. (1999)."As long as I write, I go home" [J]. Contemporary Writers Review, (01): $3-5$. 